\title{
MEMBANGUN INDONESIA YANG KUAT DARI KELUARGA "INDONESIAN STRONG FROM HOME"
}

\author{
Dr. Muhammad Faizal, M.Pd \\ STKIP Subang \\ faizal@gmail.com
}

\begin{abstract}
Indonesia is strongly built by the nation's next generation of powerfull and robust which is in the hands of early childhood. So to create the next generation a strong responsibility to be educated not only on formal institutional agencies. But the "home" is then termed "family" as an institution and the first main roles and functions that are crucial in the process of planting and establishment of the national character. Through character building in a family that includes aspects of maternal bonding, security compliance and fulfillment of physical and mental stimulation, as well as the implementation of appropriate parenting on children will build the next generation of Indonesian nation strong and resilient in facing the challenges of globalization in the future.
\end{abstract}

Keywords : character education, family, parenting parents

\section{ABSTRAK}

Indonesia yang kuat dibangun oleh para generasi penerus bangsa yang kuat dan tangguh yang berada pada tangan anak-anak usia dini. Maka untuk menciptakan generasi penerus bangsa yang kuat tanggung jawab pendidikannya tidak hanya saja berada pada lembaga institusional formal saja. Namun "rumah" yang kemudian diistilahkan "keluarga" sebagai lembaga yang utama dan pertama memiliki peran dan fungsi yang sangat krusial dalam proses penanaman dan pembentukan karakter bangsa tersebut. Melalui pembinaan karakter dalam keluarga yang meliputi aspek maternal bonding, pemenuhan rasa aman dan pemenuhan stimulasi fisik dan mental, serta pelaksanaan pola asuh yang tepat terhadap anak-anak akan membangun generasi penerus bangsa Indonesia yang kuat dan tangguh dalam menghadapi tantangan globalisasi dimasa depan.

Kata Kunci: pendidikan karakter, keluarga, pola asuh orangtua

\section{PENDAHULUAN}

Pendidikan anak usia dini merupakan pendidikan yang paling mendasar dan menempati posisi yang sangat strategis dalam pengembangan sumber daya manusia yang berkualitas dan penentu keberhasilan negara Indonesia dimasa mendatang. Mengingat anak usia dini merupakan rentang usia kritis, strategis dan periode kondusif untuk menumbuhkembangkan berbagai kemampuan fisiologis, kognitif, 
bahasa, sosioemosional dan emosional.

Sujiono (2010:2) menyatakan bahwa pendidikan adalah hal yang sangat penting untuk diperoleh semua anak karena pendidikan merupakan salah satu modal yang harus dimiliki oleh setiap individu untuk meraih kesuksesan dalam hidupnya. Keberlangsungan pendidikan bagi setiap warga negara perlu mendapat perhatian yang serius dari berbagai pihak terutama pemerintah. Peran dan tanggung jawab pemerintah terhadap pengasuhan, pendidikan dan pengembangan anak usia dini di Indonesia telah diwujudkan dalam bentuk berbagai kebijakan dan kesepakatan baik dalam lingkup nasional maupun internasional. Diantaranya amandemen UUD dasar 1945 pasal 28B ayat 2 tentang kelangsungan hidup, UU nomor 23 tahun 2003 pasal 3 tentang perlindungan anak, Undang-Undang Nomor 20 tahun 2003 tentang Sisdiknas dan kebijakan lainnya.

Berdasarkan landasan kebijakan tersebut, maka dapat dimaknai bahwa pendidikan yang diberikan pada anak usia dini merupakan intervensi lingkungan untuk mengoptimalkan pertumbuhan dan perkembangan anak. Apabila bangsa Indonesia menginginkan warga negaranya menjadi cerdas dan kuat dalam menghadapi tantangan di masa mendatang maka hak atas pendidikan perlu diberikan seluas-luasnya kepada semua golongan masyarakat sejak usia dini sampai usia lanjut.

Dalam hubungannya dengan pendidikan, Choirul (2013) menyatakan "rumah" yang dalam istilah berikutnya disebut "keluarga" merupakan lembaga pendidikan yang pertama dan utama. Keluarga merupakan dunia anak yang pertama yang memberikan sumbangan mental dan fisik terhadapnya. Melalui pendidikan dalam keluarga, anak bukan saja diharapkan agar menjadi suatu pribadi yang mantap, yang secara mandiri dapat melaksanakan tugas hidupnya yang baik, melainkan ia juga diharapkan kelak dapat menjadi generasi penerus bangsa yang kuat. Kedua segi pendidikan tersebut, kepribadian yang mantap dan generasi penerus bangsa yang kuat, fungsi pokok keluarga dalam pendidikan anak usia dini.(edukasikompas, 2009)

Melihat arti penting peran dan fungsi keluarga dalam pendidikan karakter anak usia dini, tetapi kasus-kasus yang terjadi sekarang ini seperti berbagai tindak kekerasan, tawuran antar pelajar, pelecehan seksual dan tindak kriminal lainnya yang terjadi baik dalam keluarga maupun di lingkungan lain, ataupun berbagai tindak KKN di lingkungan pemerintahan, BUMN, atau perusahaan swasta yang merugikan keuangan negara dalam hitungan yang tidak terbayangkan (Majani: 2012), mengindikasikan terjadi kesalahan dalam pelaksanaan fungsi dan peran keluarga sebagai lembaga pertama penanaman dan pembentukan karakter tersebut.

Berdasarkan fakta diatas, menjelaskan bagaimana fungsi keluarga ini sudah tidak sesuai. Keluarga khususnya orang tua lebih banyak sibuk dengan aktivitas dan profesinya diluar sehingga pendidikan anaknya terbengkalai. Selain itu pola 
asuh yang tidak tepat untuk anak, yang cenderung membebaskan anak untuk melakukan hal apapun tanpa batas dengan alasan memberikan semuanya untuk anak justru menjadikan karakter anak konsumtif, semua harus didapatkan dengan cara apapun.

Berdasarkan kondisi tersebut, makalah ini bertujuan untuk mendeskripsikan dan memberikan pemahaman kembali mengenai betapa penting peran dan fungsi keluarga sebagai lembaga pertama dan utama dalam pembentukan karakter anak menjadi kuat sehingga dapat melahirkan generasi penrus bangsa Indonesia yang tangguh secara fisik, mental dan spiritual dalam menghadapi tangtangan globalisasi dimasa mendatang.

\section{PEMBAHASAN}

\section{Karakter dan Faktor-faktor yang Mempengaruhi Perkembangannya}

Karakter didefinisikan secara berbeda-beda oleh berbagai pihak. Sebagian menyebutkan karakter sebagai penilaian subyektif terhadap kualitas moral dan mental, sementara yang lainnya menyebutkan karakter sebagai penilaian subyektif terhadap kualitas mental saja, sehingga upaya merubah atau membentuk karakter hanya berkaitan dengan stimulasi terhadap intelektual seseorang (encyclopedia.thefreedictionary.com, 2004). Sementara itu menurut Megawangi (2003), kualitas karakter meliputi sembilan pilar, yaitu (1) cinta tuhan dan segenap ciptaan-Nya; (2) tanggung jawab, disiplin dan mandiri; (3) jujur/amanah dan arif; (4) hormat dan santun; (5) dermawan, suka menolong, dan gotong-royong; (6) percaya diri, kreatif dan pekerja keras; (7) kepemimpinan dan adil; (8) baik dan rendah hati; (9) toleran, cinta damai dan kesatuan. Jadi, menurut Ratna Megawangi, orang yang memiliki karakter baik adalah orang yang memiliki kesembilan pilar karakter tersebut.

Karakter, seperti juga kualitas diri yang lainnya pada setiap individu dipengaruhi oleh faktor bawaan (nature) dan faktor lingkungan (nurture). Menurut para developmental psychologist, setiap manusia memiliki potensi bawaan yang akan termanisfestasi setelah dia dilahirkan, termasuk potensi yang terkait dengan karakter atau nilai-nilai kebajikan. Dalam hal ini, Confusius (Megawangi, 2003) menyatakan bahwa manusia pada dasarnya memiliki potensi mencintai kebajikan, namun bila potensi ini tidak diikuti dengan pendidikan dan sosialisasi dalam keluarga, maka manusia dapat berubah menjadi binatang, bahkan lebih buruk lagi. Berdasarkan pernyataan tersebut pendidikan anak yang berkaitan dengan nilai-nilai kebajikan baik di keluarga, sekolah, maupun lingkungan yang lebih luas sangat penting dalam pembentukan karakter seorang anak.

Berdasarkan paparan diatas, dapat disimpulkan bahwa karakter merupakan kualitas moral dan mental seseorang yang pembentukannya dipengaruhi oleh faktor bawaan atau fitrah (nature) dan lingkungan (sosialisasi atau pendidikan / nurture). Potensi karakter yang baik dimiliki manusia sebelum dilahirkan, tetapi potensi tersebut harus terus-menerus dibina melalui sosialisasi dan pendidikan sejak usia dini. 


\section{Pembinaan Karakter Anak yang Dilakukan oleh Keluarga}

Menurut Garbarino \& Brofenbrenner (Couchnour and Chrisman, 2008:7) suatu bangsa harus memiliki aturanaturan yang menetapkan apa yang salah dan apa yang benar, apa yang boleh dan apa yang tidak boleh dilakukan, apa yang adil dan apa yang tidak adil, apa yang patut dan tidak patut agar dapat bertahan hidup. Oleh karena itu, perlu ada etika dalam bicara, aturan dalam berlalu lintas, dan aturan-aturan sosial lainnya. selain itu manusia perlu memahami "aturan main" dalam kehidupan dunia dan menginternalisasikan dalam dirinya sehingga mampu mengaplikasikan dalam kehidupannya menjadi pembiasaan.

Perilaku yang menjadi kebiasaan baik atau buruk pada diri seseorang yang mengindikasikan kualitas karakter ini tidak terjadi dengan sendirinya. Telah disebutkan bahwa selain faktor nature, faktor nurture juga berpengaruh. Menurut Megawangi (2003), anak-anak akan tumbuh menjadi pribadi yang berkarakter apabila dapat tumbuh pada lingkungan yang berkarakter, sehingga fitrah setiap anak yang dilahirkan suci dapat berkembang segara optimal. Mengingat lingkungan anak bukan saja lingkungan keluarga yang sifatnya mikro, maka semua pihak: keluarga, sekolah, media massa, komunitas bisnis, dan sebagainya turut andil dalam perkembangan karakter anak. Dengan kata lain, mengembangkan generasi penerus bangsa yang berkarakter baik adalah tanggung jawab semua pihak yang dimulai dari keluarga.

\section{Keluarga sebagai Wahana Pertama dan Utama Pendidikan}

Para sosiolog (Majani: 2012), meyakini bahwa keluarga memiliki peran penting dalam menentukan kemajuan suatu bangsa, sehingga mereka berteori bahwa keluarga adalah unit yang penting sekali dalam masyarakat, sehingga jika keluargakeluarga yang merupakan fondasi masyarakat lemah, maka masyarakat pun akan lemah. Oleh karena itu, para sosiolog meyakini bahwa berbagai masalah masyarakat seperti kejahatan seksual dan kekerasan yang merajalela, serta segala macam kebobrokan di masyarakat merupakan akibat dari lemahnya institusi keluarga.

Bagi seorang anak, keluarga merupakan tempat pertama dan utama bagi pertumbuhan dan perkembangannya. Menurut resolusi Majelis Umum PBB (dalam Megawangi, 2003), fungsi utama keluarga adalah "sebagai wahana untuk mendidik, mengasuh, dan mensosialisasikan anak, mengembangkan kemampuan seluruh anggotanya agar dapat menjalankan fungsinya di masyarakat dengan baik, serta memberikan kepuasan dan lingkungan yang sehat guna tercapainya keluarga, sejahtera".

Menurut pakar pendidikan, William Bennett (Megawangi, 2003), keluarga merupakan tempat yang paling awal dan efektif untuk menjalankan fungsi Departemen Kesehatan, Pendidikan, dan Kesejahteraan. Apabila keluarga 
gagal untuk mengajarkan kejujuran, semangat, keinginan untuk menjadi yang terbaik, dan kemampuankemampuan dasar, maka akan sulit sekali bagi institusi-institusi lain untuk memperbaiki kegagalankegagalannya.

Yusuf (2007: 37) menambahkan keluarga memiliki peran yang sangat penting dalam upaya mengembangkan pribadi anak. Perawatan orangtua yang penuh kasih sayang dan pendidikan tentang nilai-nilai kehidupan, baik agama maupun sosial budaya yang diberikannya merupakan faktor yang kondusif untuk mempersiapkan anak menjadi pribadi dan anggota masyarakat yang sehat.

Dari paparan ini dapat disimpulkan bahwa keluarga merupakan wahana atau lembaga pertama dan utama bagi pendidikan karakter anak. Apabila keluarga gagal melakukan pendidikan karakter pada anakanaknya, maka akan sulit bagi institusi-institusi lain di luar keluarga (termasuk sekolah) untuk memperbaikinya. Kegagalan keluarga dalam membentuk karakter anak akan berakibat pada tumbuhnya masyarakat yang tidak berkarakter. Oleh karena itu, setiap keluarga harus memiliki kesadaran bahwa karakter bangsa sangat tergantung pada pendidikan karakter anak di rumah.

\section{Aspek-aspek Penting dalam Pendidikan Karakter Anak}

Untuk membentuk karakter anak diperlukan syarat-syarat mendasar bagi terbentuknya kepribadian yang baik. Menurut Megawangi (2003), ada tiga kebutuhan dasar anak yang harus dipenuhi, yaitu maternal bonding, rasa aman, dan stimulasi fisik dan mental.

Maternal bonding (kelekatan psikologis dengan ibunya) merupakan dasar penting dalam pembentukan karakter anak karena aspek ini berperan dalam pembentukan dasar kepercayaan kepada orang lain (trust) pada anak. Kelekatan ini membuat anak merasa diperhatikan dan menumbuhkan rasa aman sehingga menumbuhkan rasa percaya. Menurut Erikson, dasar kepercayaan yang ditumbuhkan melalui hubungan ibuanak pada tahun-tahun pertama kehidupan anak akan memberi bekal bagi kesuksesan anak dalam kehidupan sosialnya ketika ia dewasa. Dengan kata lain, ikatan emosional yang erat antara ibu-anak di usia awal dapat membentuk kepribadian yang baik pada anak.

Kebutuhan akan rasa aman yaitu kebutuhan anak akan lingkungan yang stabil dan aman. Kebutuhan ini penting bagi pembentukan karakter anak karena lingkungan yang berubah-ubah akan membahayakan perkembangan emosi bayi. Menurut Bowlby (Megawangi, 2003), normal bagi seorang bayi untuk mencari kontak dengan hanya satu orang (biasanya ibu) pada tahap-tahap awal masa bayi. Kekacauan emosi anak yang terjadi karena tidak adanya rasa aman dan hal ini tidak kondusif bagi pertumbuhan anak yang optimal.

Kebutuhan akan stimulasi fisik dan mental merupakan aspek penting dalam pembentukan karakter anak. Tentu saja hal ini membutuhkan perhatian yang besar dari orang tua dan reaksi timbal balik antara ibu dan 
anaknya. Menurut pakar pendidikan anak, seorang ibu yang sangat perhatian (yang diukur dari seringnya ibu melihat mata anaknya, mengelus, menggendong, dan berbicara kepada anaknya) terhadap anaknya yang berusia usia di bawah enam bulan akan mempengaruhi sikap bayinya sehingga menjadi anak yang gembira, antusias mengeksplorasi lingkungannya, dan menjadikannya anak yang kreatif.

\section{Pola Asuh Menentukan Keberhasilan Pendidikan Karakter Anak dalam Keluarga}

Keberhasilan keluarga dalam menanamkan nilai-nilai kebajikan (karakter) pada anak sangat tergantung pada jenis pola asuh yang diterapkan orang tua pada anaknya. Pola asuh dapat didefinisikan (Darling, 2009) bahwa "Parenting style is a psychological construct representing standard strategies that parents use in their child rearing". Dapat diartikan sebagai pola asuh adalah konstruksi psikologi yang mewakili standar strategi orang tua digunakan untuk membesarkan anak mereka. Selain itu pola asuh orang tua merupakan pola interaksi antara anak dengan orangtua yang meliputi pemenuhan kebutuhan fisik dan kebutuhan psikologis serta sosialisasi norma-norma yang berlaku di masyarakat agar anak dapat hidup selaras dengan lingkungannya. Dengan kata lain, pola asuh juga meliputi pola interaksi orang tua dengan anak dalam rangka pendidikan karakter anak.

Secara umum, menurut Baumrind (dalam Papalia, Olds \& Feldman, 2009: 300), menyatakan bahwa model pola asuh yang biasa diterapkan kepada anak adalah: Pertama, Authoritative. Dalam pola asuh ini orang tua menghargai keperibadian anak-anaknya tetapi juga menitikberatkan pada pemaksaan. Mereka percaya pada kemampuannya untuk menuntun anak-anaknya tetapi mereka juga menghargai keputusan yang mandiri dari anak-anaknya, minatnya, pilihannya dan kepribadiannya. Mereka penyayang dan penerima tetapi juga meminta anak-anaknya berperilaku baik dan mereka tetap mempertahankan standarnya dan mereka dapat menentukan batasannya. Mereka juga menghukum dengan bijaksana. Kedua, Authoritharian. Dalam pola asuh ini orang tua mencoba untuk membuat anak-anaknya memenuhi standar dari perilakunya, kewenangannya untuk menghukum dan penuh ketegasan. Mereka lebih objektif dan kurang hangat dari orang tua lainnya. Ketiga, Permissive. Dalam pola asuh ini orang tua serba membolehkan, mandiri, self expresion dan self regulation. Para orang tua lebih mempertimbangkan pada kemampuan sumbernya, bukan pada modelnya. Mereka pada umumnya membuat beberapa permintaan dan membolehkan anak-anak untuk dapat memonitor kegiatan orang tua sebanyak mungkin. Ketika mereka membuat peraturan, mereka menjelaskan alasan mereka. Mereka juga membicarakannya dengan anakanak mengenai keputusan dari kebijaksanaannya dan jarang menghukum. Mereka bersahabat, tidak mengawasi dan tidak memaksa.

Maccoby \& Martin (dalam Papalia, Olds \& Feldman, 2009: 303) 
mengemukakan bahwa pengasuhan yang permissive terjadi dalam dua bentuk, yaitu Permissive indifferent ialah suatu gaya pengasuhan (pola asuh) dimana orang tua sangat tidak terlihat dalam kehidupan anak. Pola asuh permissive indifferent dapat diidentifikasikan sebagai tipe penelantar atau mengabaikan. Orang tua tipe ini pada umumnya memberikan waktu dan biaya yang sangat minim pada anak-anaknya. Waktu mereka banyak digunakan untuk keperluan pribadi mereka, seperti bekerja, dan juga kadangkala biayapun dihemat-hemat untuk anak mereka. Hubungan orang tua permissive indifferent biasanya ditandai dengan kontrol yang rendah dan kehangatan yang rendah pula. Permissive indulgent ialah suatu gaya pengasuahan (pola asuh) dimana orang tua sangat terlihat dalam kehidupan anak-anak mereka tetapi menetapkan sedikit batas atau kendali terhadap anak-anaknya. Hubungan orang tua permissive indulgent dapat diidentifikasikan sebaagai tipe memanjakan yang biasanya ditandai dengan kontrol yang rendah dan kehangatan yang tinggi

Hasil penelitian Rohner (dalam Megawangi, 2003) menunjukkan bahwa pengalaman masa kecil seseorang sangat mempengaruhi perkembangan kepribadiannya. Dengan menggunakan teori $P A R$ (Parental Acceptanc-Rejection Theory) menunjukkan bahwa pola asuh orang tua, baik yang menerima (acceptance) atau yang menolak (rejection) anaknya, akan mempengaruhi perkembangan emosi, perilaku, sosial-kognitif, dan kesehatan fungsi psikologisnya ketika dewasa kelak. Pola asuh orang tua yang menerima membuat anak merasa disayang, dilindungi, dianggap berharga, dan diberi dukungan oleh orang tuanya. Pola asuh ini sangat kondusif mendukung pembentukan kepribadian yang prososial, percaya diri, dan mandiri namun sangat peduli dengan lingkungannya. Sementara itu, pola asuh yang menolak dapat membuat anak merasa tidak diterima, tidak disayang, dikecilkan, bahkan dibenci oleh orang tuanya. Anak-anak yang mengalami penolakan dari orang tuanya akan menjadi pribadi yang tidak mandiri, atau kelihatan mandiri tetapi tidak mempedulikan orang lain. Selain itu anak ini akan cepat tersinggung, dan berpandangan negatif terhadap orang lain dan terhadap kehidupannya, bersikap sangat agresif kepada orang lain, atau merasa minder dan tidak merasa dirinya berharga.

Menurut Megawangi (2003) beberapa kesalahan orang tua dalam mendidik anak yang dapat mempengaruhi perkembangan kecerdasan emosi anak sehingga berakibat pada pembentukan karakternya, yaitu : (1) kurang menunjukkan ekspresi kasih sayang baik secara verbal maupun fisik. (2) kurang meluangkan waktu yang cukup untuk anaknya. (3) bersikap kasar secara verbal, misainya menyindir, mengecilkan anak, dan berkata-kata kasar. (4) bersikap kasar secara fisik, misalnya memukul, mencubit, dan memberikan hukuman badan lainnya. (5) terlalu memaksa anak untuk menguasai kemampuan kognitif secara dini. (6) tidak menanamkan "good character' kepada anak. Dampak yang ditimbulkan dari salah asuh seperti di atas, menurut akan menghasilkan 


$\begin{array}{lcr}\text { anak-anak } & \text { yang } & \text { mempunyai } \\ \text { kepribadian } & \text { bermasalah } & \text { atau } \\ \text { mempunyai } & \text { kecerdasan emosi } \\ \text { rendah. } & & \end{array}$

Dari paparan di atas jelas bahwa jenis pola asuh yang diterapkan orang tua kepada anaknya sangat menentukan keberhasilan pendidikan karakter anak. Kesalahan dalam pengasuhan anak akan berakibat pada kegagalan dalam pembentukan karakter yang baik.

\section{KESIMPULAN}

Karakter merupakan kualitas moral dan mental seseorang yang pembentukannya dipengaruhi oleh faktor bawaan atau fitrah (nature) dan lingkungan (sosialisasi atau pendikan/nurture). Potensi karakter yang baik dimiliki manusia sebelum dilahirkan, tetapi potensi tersebut harus terus-menerus dibina melalui pendidikan keluarga sejak usia dini.

Semua pihak bertanggung jawab atas pendidikan karakter calon generasi penerus bangsa (anak-anak), tetapi keluarga merupakan lembaga pertama dan utama bagi pendidikan karakter anak. Untuk membentuk karakter anak keluarga harus memenuhi tiga syarat dasar bagi terbentuknya kepribadian yang baik, yaitu maternal bonding, rasa aman, dan stimulasi fisik dan mental. Selain itu, jenis pola asuh yang diterapkan orang tua kepada anaknya juga menentukan keberhasilan pendidikan karakter anak di rumah.

Kesalahan dalam pengasuhan anak di keluarga akan berakibat pada kegagalan dalam pembentukan karakter yang baik. Kegagalan keluarga dalam melakukan pendidikan karakter pada anakanaknya, akan mempersulit institusiinstitusi lain di luar keluarga (termasuk sekolah) dalam upaya memperbaikinya. Kegagalan keluarga dalam membentuk karakter anak akan berakibat pada tumbuhnya masyarakat yang tidak berkarakter. Oleh karena itu, setiap keluarga harus memiliki kesadaran bahwa karakter bangsa sangat tergantung pada pendidikan karakter anak-anak mereka dalam keluarga. Berdasarkan paparan untuk membangun Indonesia yang kuat yang tangguh dan berkarakter bisa dimulai dengan pola asuh yang tepat, pelaksanaan pendidikan dan penanaman karakter para generasi penerus bangsa (anakanak usia dini ) dari dalam keluarga kita.

\section{DAFTAR PUSTAKA}

Counchour, Donna and Chrissman Kent. (2008). Families, School and Communites Together For young Children. Third Edition. United States: Thomson Delmar learning

Darling, Nancy. (2009). Parenting Style and Its Correlates. Journal of Clearinghouse on Elementary and Early Childhood Education, University of Illionis, ERIC DIGEST,2009)

http://ecap.crc.illinois.edu/eecearchive /digests/1999/darlin99.pdf. (diakses 18 pebruari 2013)

Megawangi, Ratna. (2003). Pendidikan Karakter untuk Membangun Masyarakat Madani. IPPK Indonesia Heritage Foundation 
Papalia, Diane E., Olds, Sally Wendkos \& Feldman, Ruth Duskin. (2009). Human Development. New York: McGraw-Hill Cimpanies, Inc,.

Sujiono, Yuliani Nurani. (2011). Konsep Dasar Pendidikan Anak Usia Dini. Jakarta: Indeks.

Sutanto, Choirul. (2013). Peran keluarga dalam Pendidkan dan Sosial Budaya. tersedia dalam http://sutantochairul.blogspot.com/201 3/04/makalah-sosial-budayapendidikan.html [tanggal akses: 31 Oktober 2013]

Majani. (2012). Peran Keluarga Dalam pendidikan. tersedia dalam: http://makalahmajannaii.blogspot.com /2012/11/peran-keluarga-dalampendidikan.html. [tanggal akses: 31 Oktober 2013]

Yusuf, Syamsu. (2002). Psikologi Perkembangan Anak dan Remaja. Bandung: Rosdakarya.

http://edukasi.kompas.com/read/2009/ 08/01/16074946/banyak.ortu.belum.s adar.pentingnya.paud [tanggal akses: 31 Oktober 2013] 